\title{
Triple Cropping Systems of Spring Maize, Tropical Grass of Teff (Eragrostis tef) and Winter Cereal Crops to Combine Total Digestible Nutrient Yield with Protein Concentration in Southern Kyushu, Japan
}

\author{
Yukimi Nakata, Sachiko Idota*, Manabu Tobisa, Yasuyuki Ishii \\ Faculty of Agriculture, University of Miyazaki, Miyazaki, Japan \\ Email: spade02-phoenix01.dreammaiden@docomo.ne.jp, *sidota@cc.miyazaki-u.ac.jp, mtobisa@cc.miyazaki-u.ac.jp, \\ yishii@cc.miyazaki-u.ac.jp
}

How to cite this paper: Nakata, Y., Idota, S., Tobisa, M. and Ishii, Y. (2018) Triple Cropping Systems of Spring Maize, Tropical Grass of Teff (Eragrostis tef) and Winter Cereal Crops to Combine Total Digestible Nutrient Yield with Protein Concentration in Southern Kyushu, Japan. Agricultural Sciences, 9, 129-140. https://doi.org/10.4236/as.2018.91010

Received: January 5, 2018

Accepted: January 27, 2018

Published: January 30, 2018

Copyright (c) 2018 by authors and Scientific Research Publishing Inc. This work is licensed under the Creative Commons Attribution International License (CC BY 4.0).

http://creativecommons.org/licenses/by/4.0/

\begin{abstract}
It is ordinarily common for forage production in southern Kyushu to adopt a double cropping system, composed of summer forage crops (e.g. maize and sorghum) cultivated from late March to early September, and winter grass crops (e.g. Italian ryegrass (IR) and oat) from mid-October to the following May. However, if high total digestible nutrient (TDN) production is aimed to introduce winter cereal crops (e.g. wheat and barley) as a replacement of IR, it is necessary to cultivate tropical grass, which has a rapid-growth potential with high crude protein $(\mathrm{CP})$ concentration in a switching period between summer and winter crops. In this study, teff (Eragrostis tef) was tried to evaluate as a candidate crop in the switching period. Yield and quality of two types of triple forage cropping system were determined under maize-teff-barley and maize-teff-wheat in the first and second year, respectively. Compared with the normal year, summer temperature was higher and summer and winter precipitations were lower in the first year, while no climatic disorder was observed in the second year. Even though dry matter yield of teff was minimal in the present system due to weed damage, CP concentration was the highest among crops and TDN yields of the present cropping system tended to be higher in the second year with no drought stress than in the conventional maize-IR system in the region.
\end{abstract}




\section{Keywords}

Cropping System, Dry Matter Yield, Eragrostis tef, Forage Quality, Growth Attribute

\section{Introduction}

Since climatic conditions of annual temperature at $17.0^{\circ} \mathrm{C}$ and annual precipitation above $2500 \mathrm{~mm}$ are suitable to a double cropping system of soiling crops production in southern Kyushu, summer crops such as maize (Zea mays L.) and sorghum (Sorghum bicolor Moench) are ordinarily cultivated from late March to early September and winter crops such as Italian ryegrass (Lolium multiflorum Lam., IR) and oat (Avena sativa L.) from mid-October to the following May. Annual use of tropical grasses such as Rhodes grass (Chloris gayana Kunth) and Guinea grass (Panicum maximum Jacq.) is also applied as hay and haylage production as a replacement of summer soiling crops in the region, however, there are no promising grasses which have so short growing days around two months to be matured as to meet to grow in the switching period from summer to winter soiling crops. Reduction of feeding cost in animal production is in a high demand for livestock farmers in the region, since mixed feed price increased by $17.4 \%$ over seven years from 2009 to 2016 [1]. Therefore, multi-cropping rather than the conventional double-cropping system can be applicable to southern Kyushu, if some novel forage species is introduced to fit to the short growth property in a hot summer season.

Teff (Eragrostis tef (Zuccagni) Trotter) is cultivated as a staple food crop in Ethiopia for many centuries [2] with self-pollinated and annual tropical grass species. Recently, this food crop has an attention as gluten-free and high content of minerals, which is an alternative to wheat [3] [4]. The grass can be grown in so wide range of soil and environmental conditions as drought and water-logging soils [5]. Superior growth attributes of this species are early-matured within two months [2], has thin stems suitable for hay production and high adaptability to poor permeability soil with little drought damage. In the present century, the grass species has been examined for forage crops fed to horses and cattle, and its cultivation has just started in the USA [6]. Research in the USA for teff proved to show dry matter yield in a range of 1000 to $1750 \mathrm{~g} \cdot \mathrm{m}^{-2}$, depending on the growing period [7], and be adequate for a rotational crop in the USA [8]. However, the grass is quite new to be cultivated in southern Kyushu, Japan. Barley (Hordeum vulgare L.) and wheat (Triticum aestivum L.) are also used as winter forage crops suitable for silage-processing in the region. Therefore, in the present study, newly introduced tropical grass of teff was tried to be cultivated in the switching period from summer to winter crops, and yield and quality of triple forage cropping system of maize, teff and other cereal crops of barley or 
wheat were determined for two cropping seasons in southern Kyushu.

\section{Materials and Methods}

\subsection{Cultivation and Measurement}

This experiment was carried out in the University of Miyazaki, southern Kyushu, Japan $\left(31^{\circ} 49^{\prime} \mathrm{N}, 131^{\circ} 24^{\prime} \mathrm{E}\right)$ in May 2013 to May 2015. Table 1 showed sowing and harvesting seasons in the present triple cropping system. In the first year, we cultivated maize (cv. Snow dent 110), teff (cv. Tiffany) and barley (cv. Wasedori-nijyou). In the second year, the same cultivar of maize was used as in the first year, while cultivar of teff was changed to $\mathrm{cv}$. Moxie and winter grass crop was changed to wheat (cv. Chikugoizumi and Minaminokaori). Maize was sown in a spacing of $20 \mathrm{~cm}$ intra-row and $75 \mathrm{~cm}$ interrow at a density of 6.67 plants $\cdot \mathrm{m}^{-2}$. Teff and barley were broadcast-sown uniformly at 1.3 and $3.0 \mathrm{~g} \cdot \mathrm{m}^{-2}$, respectively. Both wheat cultivars were broadcast-sown at $3.0 \mathrm{~g} \cdot \mathrm{m}^{-2}$ in November. Plot size was $9 \mathrm{~m}^{2}$, with $0.5 \mathrm{~m}$ space between plots. The plot was arranged in a completely randomized block design with three replications. Plant growth attributes measured were plant length, tiller number, heading tiller number and SPAD index (SPAD 502 meter, Minolta, Osaka, Japan). Plants were fractionated to leaf blade, stem, and dead leaves. Fresh matter and dry matter (DM) weights were determined at monthly intervals. Plant parts were ground to pass through a $1 \mathrm{~mm}$ screen and were analyzed for in vitro dry matter digestibility (IVDMD) [9], total nitrogen, total carbon and general component composition. Crude protein $(\mathrm{CP})$ was determined by calculating total nitrogen content $\times 6.25$. Crude ash (CA), crude fat (EE) and crude fiber (CF) were determined by dry ash method, ether extract method and ANKOM Technology-9/99 using a filter bag method, respectively. TDN content for all crops, except for the first-year maize was estimated by the following equation:

Table 1. Cultivation calendar in this study and conventional maize and Italian ryegrass (IR) system.

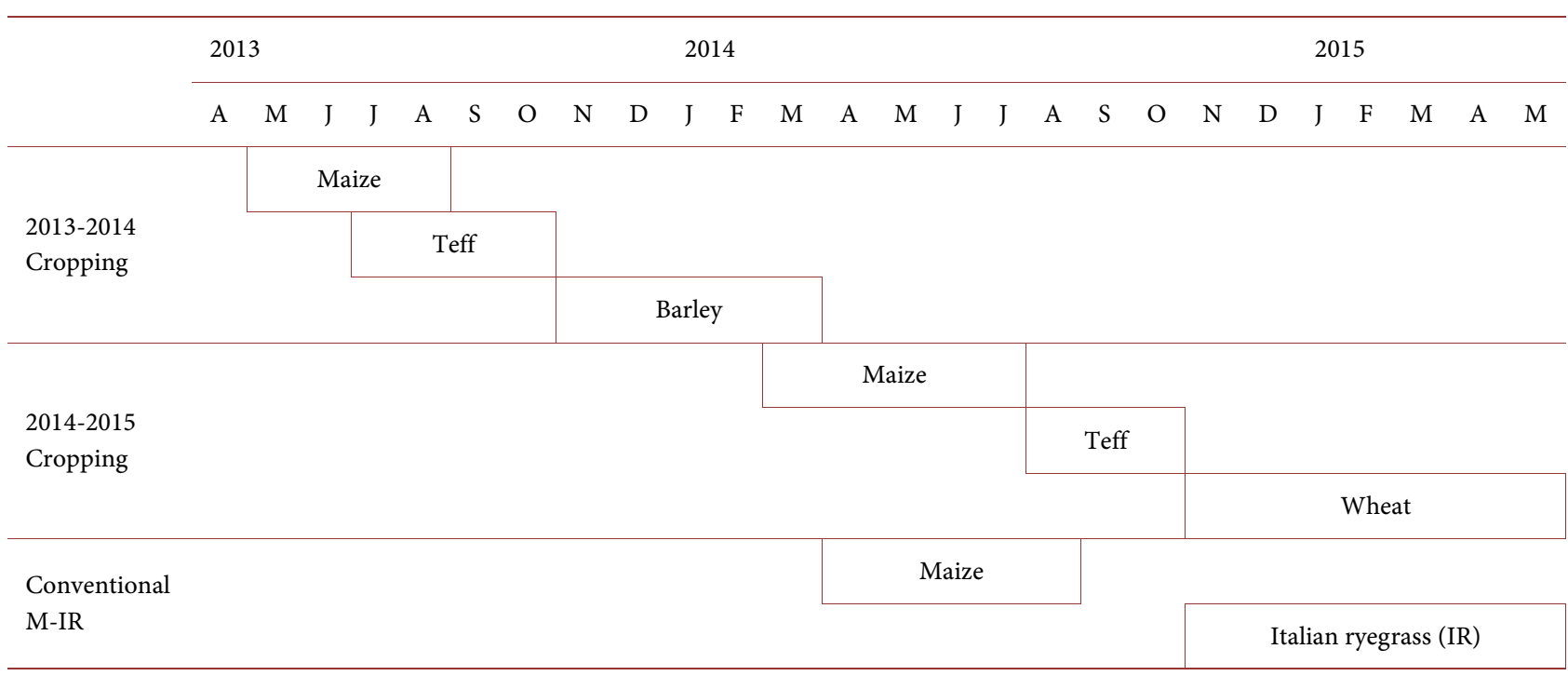


$\operatorname{TDN}(\%)=\{\mathrm{CP}(\%) \times \operatorname{IVDMD}(\%)+2.25 \times \mathrm{EE}(\%) \times \operatorname{IVDMD}(\%)+$ nitrogen free extract $(\mathrm{NEF}, \%) \times \operatorname{IVDMD}(\%)+\mathrm{CF}(\%) \times \operatorname{IVDMD}(\%)\} \times 0.01$,

and that for the first-year maize was estimated by the corresponding regression equation:

$\operatorname{TDN}(\%)=$ ratio of ear $\times 0.885+(100-$ ratio of ear $) \times 0.528-3.2[10]$.

\subsection{Genotypes Examined}

Maize cultivar "Snow dent 110" has high DM yield with lodging resistance. Teff cultivar "Tiffany" is now a leading variety in the U.S. and "Moxie Teff" is a high yielding with highly palatable cultivar. Since seed size of Teff is very small, therefore Teff needs soil compaction at the sowing to maintain good establishment. In the second year, Teff variety "Moxie" is adopted since it is sold as coated seed, which should facilitate the establishment. Barley cultivar "Wasedori-nijyo" is an extremely early-maturing type with lodging resistance. The cultivars of wheat are used to edible varieties for bread and noodles. Wheat cultivar "Chikugoizumi", is an early-maturing type with disease tolerance to abnormally early-ripening season and leaf rustfungi [11]. Wheat cultivar "Minaminokaori", has high crude protein content [12] with disease tolerance to wheat yellow mosaic virus.

\subsection{Statistical Analysis}

Analysis of variance (ANOVA) was performed using Excel Statistics (OMS Co. Ltd., Saitama) by one-way analysis procedures for growth attributes of maize, Teff and wheat in a randomized complete design. Mean separation was tested using the Tukey-Kramer method at the 5\% level. Student's t-test at the 5\% level was applied to analyze the differences in yield attributes of each crop between two growing seasons.

\section{Results}

\subsection{Climatic Conditions}

Monthly precipitation in July and August in the first growing season (2013) was lower than in the normal year averaged in 1980-2010, while the mean air temperature in the corresponding months was higher by $2^{\circ} \mathrm{C}$ than in the normal year (Figure 1), showing that the summer weather condition had high temperature with low precipitation. In the second season (2014), mean air temperature was the same as in the normal, while precipitation in February and August was higher than in the normal year.

\subsection{Plant Growth}

In the first growing season, plant length in maize increased rapidly from mid-June to mid-July and continued to increase consistently up to heading stage in early August (Figure 2). SPAD value in leaf blade of maize was determined at 


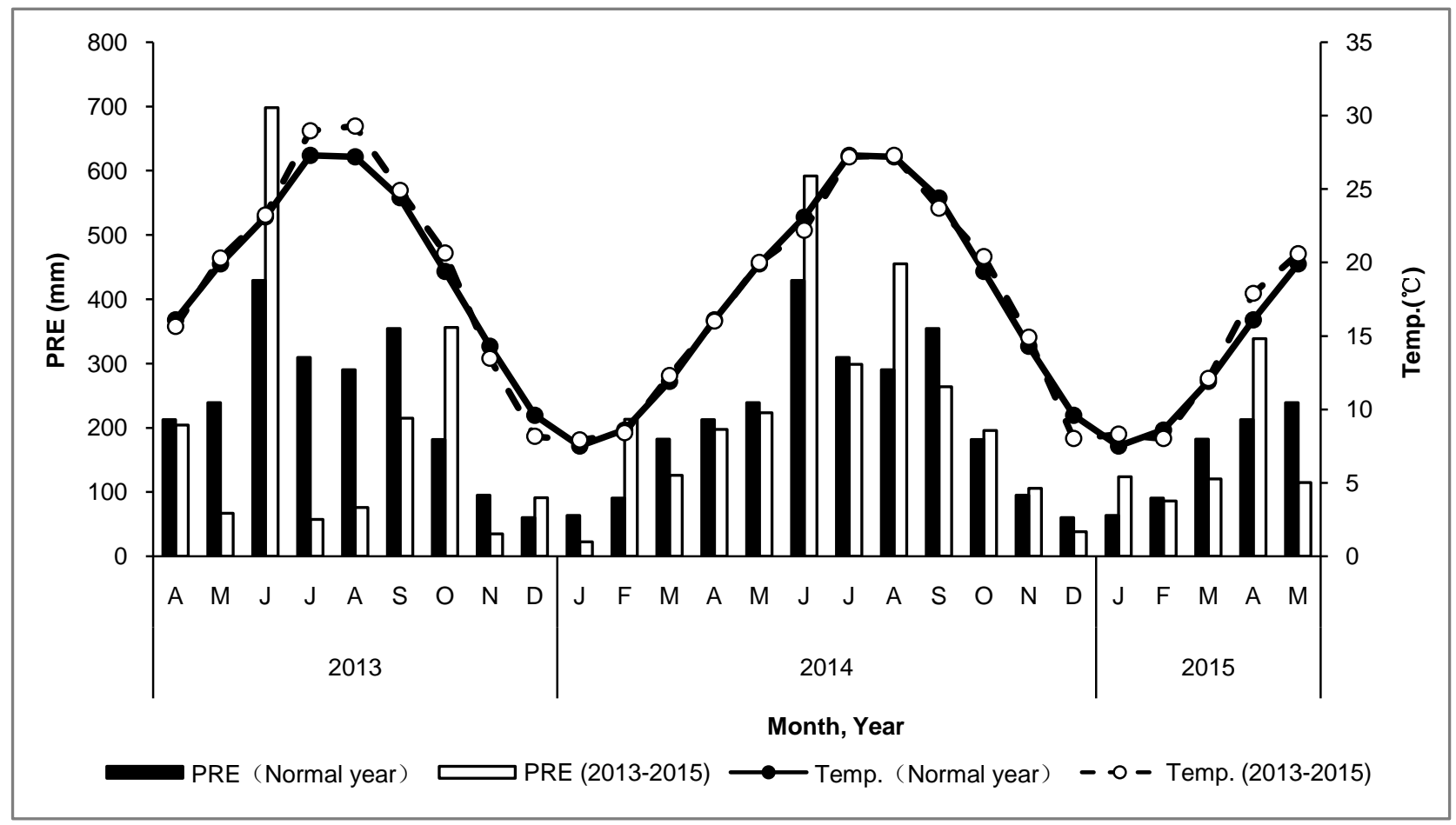

Figure 1. Changes in mean air temperature (Temp) and precipitation (PRE) in growing seasons from 2013 to 2015 and in the normal year (averaged in 1981-2010).

40 in June, while it dropped to 30 due to drought stress under low precipitation in July. In early August, an amount of rainfall at $100 \mathrm{~mm}$ led to rise SPAD value to 42 . In the second growing season, plant length and SPAD value in maize significantly increased with time up to early July to reach the maximum SPAD value at 42 (Figure 2). As for teff in both the first and second seasons, plant length increased with time from sowing to reach the peak around $85-88 \mathrm{~cm}$ in early September, and then decreased to $52-68 \mathrm{~cm}$ at the harvest in early October due to lodging (Figure 3). As for barley in the first season, plant length and tiller density were $95 \mathrm{~cm}$ and 2233 per $\mathrm{m}^{2}$ at the harvest (Table 2). Among two cultivars of wheat in the second season, "Chikugoizumi" tended to be higher in plant length and tiller density at $103 \mathrm{~cm}$ and 344 per $\mathrm{m}^{2}$, respectively at the harvest than "Minaminokaori" at $97 \mathrm{~cm}$ and 325 per $\mathrm{m}^{2}$, respectively (Table 2). Tiller density in both cultivars of wheat peaked in the end of December, then dropped to early February, probably due to cold weather damage, recovered to early March, and then slightly thinned due to stem elongation (Figure 4).

\subsection{Herbage Quality}

In five cereal crops, even though teff was not fractionated, maize, barley and two cultivars of wheat were fractionated to plant parts and determined for compositions of general chemical components, IVDMD and TDN (Table 3), showing similar tendency in general chemical components among plant fractions (Table 3). Compared with the other plant parts, leaf blade had the highest composition 

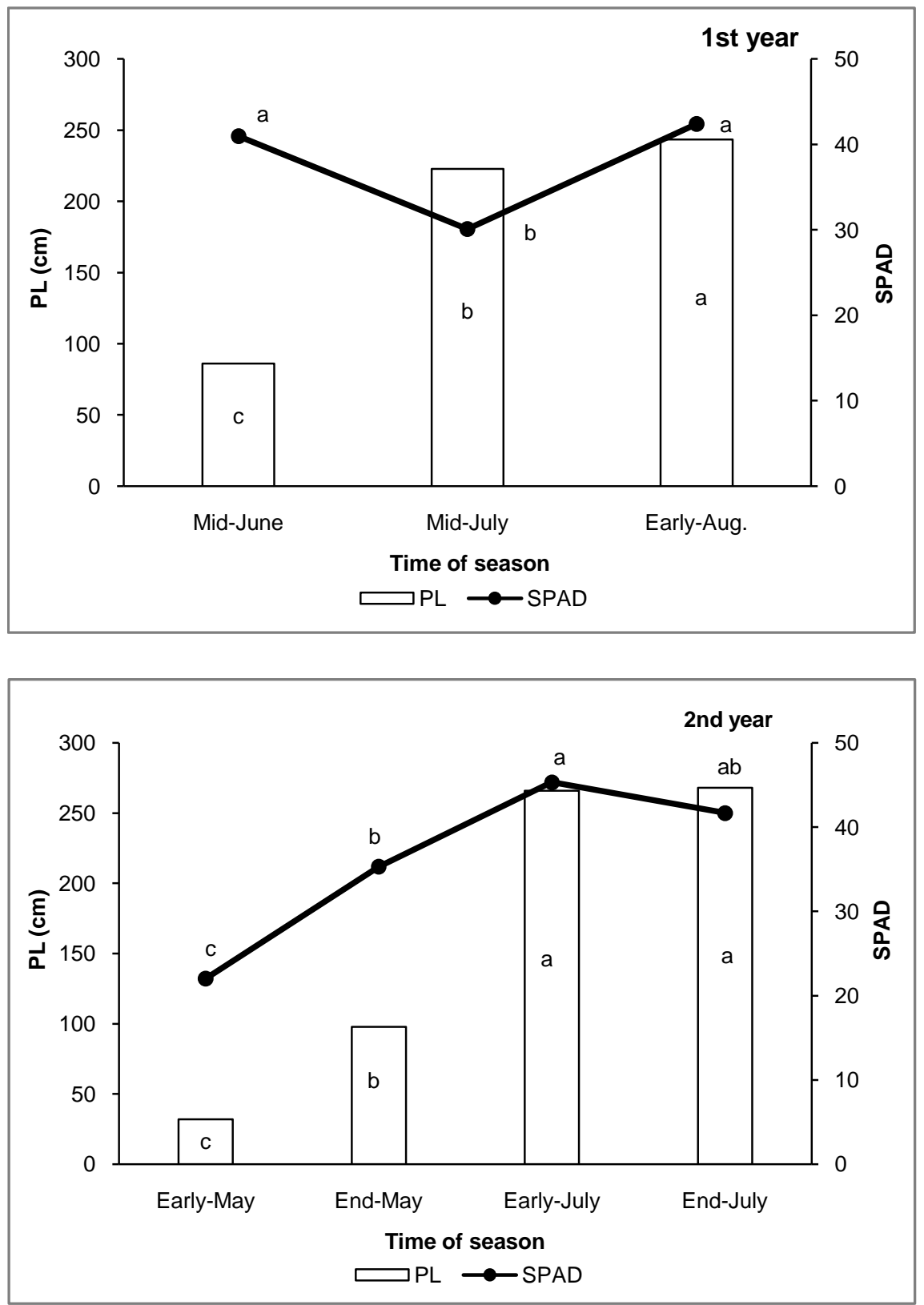

Figure 2. Plant length (PL) and SPAD of leaf blade in maize in the first and second seasons. SPAD is the index of leaf color. Significant differences $(P<0.05)$ were found in plant characters between time of season based on Tukey-Kramer multiple comparison test.

in $\mathrm{CP}, \mathrm{EE}$ and $\mathrm{CA}$ among maize, barley and two cultivars of wheat, stem the highest in CF and ear the highest in NFE, except for CP composition in two cultivars of wheat having comparable composition in head. In whole plants, IVDMD was $77.2 \%, 86.1 \%, 73.8 \%$ and $72.4 \%$ in maize, barley, wheat cv. "Chikugoizumi" and "Minaminokaori", respectively. Compared with data in Standard Tables of Feed Composition in Japan [13], CF content was lower and EE content was higher in the current study. CP content in teff was $14.3 \%$ and $10.2 \%$ 


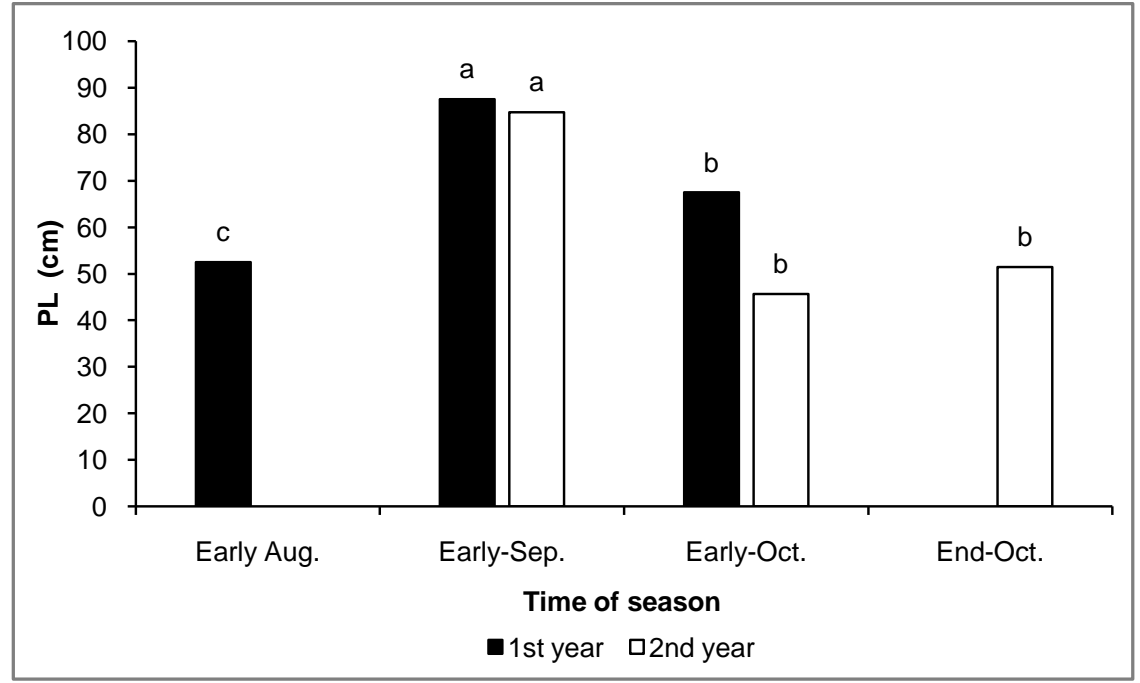

Figure 3. Plant length (PL) in Teff in the first and second seasons. Significant differences $(\mathrm{P}<0.05)$ were found in plant length between time of season based on Tukey-Kramer multiple comparison test.

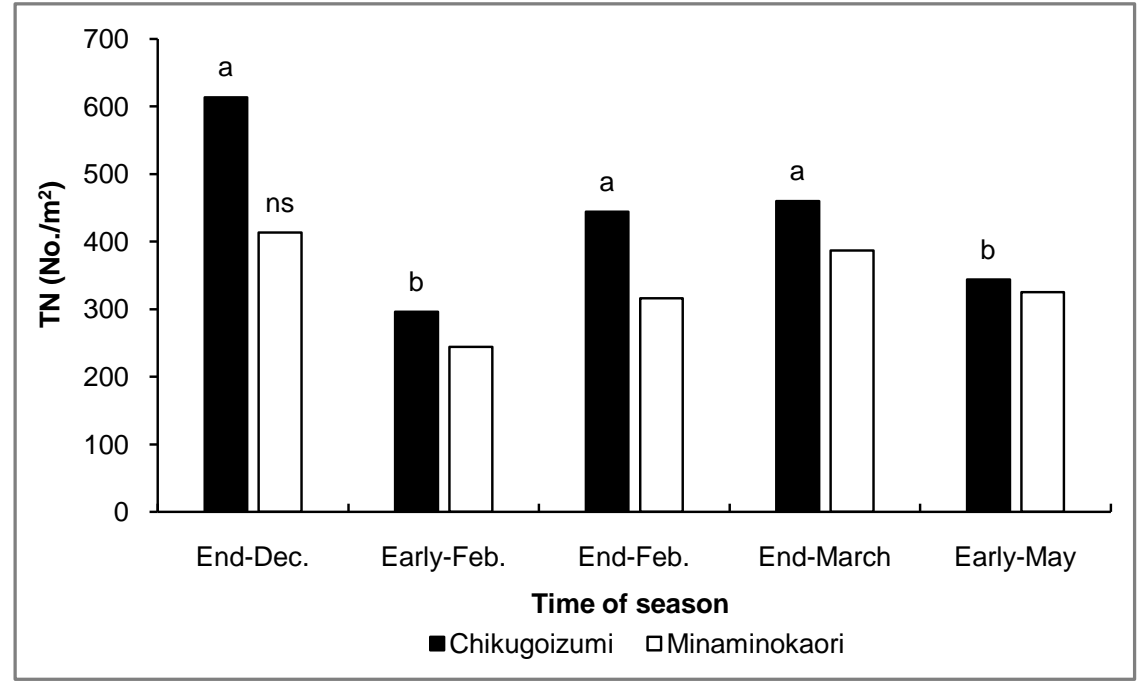

Figure 4. Changes of tiller number (TN) of wheat in the second season. Significant differences $(\mathrm{P}<0.05)$ were found in tiller number between time of season based on $\mathrm{Tu}$ key-Kramer multiple comparison test.

Table 2. Plant length (PL), SPAD value and tiller number (TN) at harvesting day in triple cropping system in the first and second seasons.

\begin{tabular}{|c|c|c|c|c|c|c|}
\hline \multirow{2}{*}{ Crop } & \multicolumn{3}{|c|}{$2013-2014$} & \multicolumn{3}{|c|}{ 2014-2015 } \\
\hline & PL (cm) & SPAD value & TN $\left(\right.$ No. $\left./ \mathrm{m}^{2}\right)$ & $\mathrm{PL}(\mathrm{cm})$ & SPAD value & $\mathrm{TN}\left(\mathrm{No} . / \mathrm{m}^{2}\right)$ \\
\hline Spring Maize & 243.6 & 42.4 & 6.7 & $268.0^{*}$ & 41.7 & 6.7 \\
\hline Teff & 67.5 & 35.2 & 580.0 & 51.5 & - & 333.0 \\
\hline Barley & 94.6 & 43.0 & 2233.3 & & & \\
\hline Wheat cv. Chikugoizumi & & & & 102.9 & - & 344.0 \\
\hline Wheat cv. Minaminokaori & & & & 96.8 & - & 325.3 \\
\hline
\end{tabular}

\footnotetext{
${ }^{*}: \mathrm{p}<0.05$.
} 
in the first and second growing season, respectively, while IVDMD and TDN content of teff were higher in the second than in the first season due to the higher IVDMD (Table 3). In the current study, barley as a whole plant had the highest in CP, IVDMD and TDN content, followed by maize and wheat cv. "Chikugonoizumi" and "Minaminokaori", while teff was variable from higher IVDMD and TDN content in the second season to the lower values in the first season (Table 3).

\subsection{Total Dry Matter Yield and TDN Yield}

DM yield of each plant fraction was determined at the harvest in the two growing seasons (Table 4). As winter crop, barley and wheat were incorporated into the present triple cropping in the first and second season, respectively. As for spring maize, DM yield increased from the first to the second year mainly due to the doubled DM accumulation of ear fraction in the second year. Reduction in teff yield in the second year was due to the lower DM accumulation in the stem fraction than in the first year. Increase in wheat DM yield in the second season was due to DM accumulation in stem and ear fractions, compared with barley in the first season (Table 4).

Table 3. General component composition, in vitro dry matter digestibility (IVDMD) and total digestible nutrients (TDN) of each crop in the second season (2014-2015).

\begin{tabular}{|c|c|c|c|c|c|c|c|c|}
\hline \multirow{2}{*}{ Crop } & \multirow{2}{*}{ Plant part } & \multicolumn{5}{|c|}{ General component composition (\% DM) } & \multirow{2}{*}{ IVDMD (\%) } & \multirow{2}{*}{ TDN $(\%)$} \\
\hline & & $\mathrm{CP}$ & $\mathrm{EE}$ & $\mathrm{CF}$ & NFE & Crude ash & & \\
\hline \multirow[t]{4}{*}{ Maize } & Leaf blade & 12.4 & 5.0 & 18.6 & 45.5 & 10.2 & 86.0 & 75.6 \\
\hline & Stem & 2.1 & 0.8 & 28.8 & 57.0 & 5.6 & 60.7 & 54.5 \\
\hline & Ear & 6.1 & 3.7 & 11.1 & 70.5 & 1.7 & 84.9 & 81.6 \\
\hline & Whole & 6.7 & 3.2 & 19.5 & 57.7 & 5.8 & 77.2 & 70.2 \\
\hline \multirow[t]{4}{*}{ Barley } & Leaf blade & 26.2 & 6.6 & 12.3 & 30.8 & 14.3 & 96.8 & 81.4 \\
\hline & Stem & 8.3 & 1.4 & 25.2 & 50.2 & 6.5 & 78.7 & 68.4 \\
\hline & Head & 11.0 & 2.1 & 17.4 & 53.3 & 6.8 & 82.7 & 71.4 \\
\hline & Whole & 14.6 & 3.4 & 18.3 & 44.8 & 9.2 & 86.1 & 73.4 \\
\hline \multirow[t]{2}{*}{ Teff } & 1 st year & 14.3 & 2.1 & 31.9 & 34.0 & 11.9 & 52.8 & 44.8 \\
\hline & 2nd year & 10.2 & 2.3 & 18.7 & 48.9 & 10.2 & 78.7 & 65.4 \\
\hline \multirow{2}{*}{ Wheat cv. Chikugoizumi } & Leaf blade & 10.3 & 6.4 & 19.1 & 39.2 & 12.9 & 92.0 & 76.5 \\
\hline & Stem & 2.3 & 0.9 & 31.6 & 53.0 & 4.7 & 55.6 & 49.4 \\
\hline \multirow{6}{*}{ Wheat cv. Minaminokaori } & Head & 10.9 & 2.3 & 13.7 & 59.7 & 5.0 & 73.7 & 66.0 \\
\hline & Whole & 5.6 & 2.4 & 16.1 & 50.6 & 5.7 & 73.8 & 57.4 \\
\hline & Leaf blade & 10.0 & 5.9 & 23.0 & 37.7 & 13.1 & 88.0 & 74.0 \\
\hline & Stem & 3.0 & 1.2 & 31.9 & 51.1 & 5.8 & 52.3 & 46.3 \\
\hline & Head & 11.5 & 2.4 & 12.0 & 61.8 & 4.9 & 76.9 & 69.7 \\
\hline & Whole & 6.7 & 2.4 & 16.7 & 50.2 & 6.0 & 72.4 & 57.2 \\
\hline
\end{tabular}

CP: crude protein; EE: crude fat; CF: crude fiber; NEF: nitrogen free extract. 
Annual total of DM and TDN yields of the two-year cropping were compared in Figure 5. Total DM and TDN yields in the second growing season were significantly higher than those in the first season. In the first and second seasons, DM yield of maize was 1,312 and $1,780 \mathrm{~g} \cdot \mathrm{m}^{-2}$, respectively, however, teff $\mathrm{cv}$. "Tiffany" and "Moxie" poorly yielded 317 and $92.9 \mathrm{~g} \cdot \mathrm{m}^{-2}$, respectively, due to weed damage. "Moxie" is sold as coated seed and so the establishment under adverse conditions is improved, leading to increase in DM yield. However, in the present study, the germination of coated seed "Moxie" was slower than the pure seed "Tiffany". Therefore, the early growth of "Moxie" was slower than that of "Tiffany", leading to the suppression of growth of "Moxie" by summer weed. In winter crops, DM yield of wheat in the second season was higher than that of barley in the first season. In the current study, annual total of DM yield was higher in the second season at $2,637 \mathrm{~g} \cdot \mathrm{m}^{-2}$ than in the first season at $2,044 \mathrm{~g} \cdot \mathrm{m}^{-2}$ and TDN yield was in the same order at $1,749 \mathrm{~g} \cdot \mathrm{m}^{-2}$ than in the first season at $1,270 \mathrm{~g} \cdot \mathrm{m}^{-2}$. Compared with the statistical data [13] [14], total DM and TDN

Table 4. Dry matter yield of each plant fraction of crops in the first (2013-2014) and the second (2014-2015) seasons.

\begin{tabular}{|c|c|c|c|c|c|c|c|c|c|c|c|c|}
\hline \multirow[b]{2}{*}{ Crop } & \multicolumn{6}{|c|}{$2013-2014$} & \multicolumn{6}{|c|}{ 2014-2015 } \\
\hline & $\begin{array}{l}\text { Leaf } \\
\text { blade }\end{array}$ & Stem & $\begin{array}{l}\text { Head } \\
\text { (Tassel) }\end{array}$ & Ear & $\begin{array}{c}\text { Dead } \\
\text { part }\end{array}$ & Whole & $\begin{array}{l}\text { Leaf } \\
\text { blade }\end{array}$ & Stem & $\begin{array}{c}\text { Head } \\
\text { (Tassel) }\end{array}$ & Ear & $\begin{array}{c}\text { Dead } \\
\text { part }\end{array}$ & Whole \\
\hline Spring maize & 182.3 & 570.8 & 11.5 & 484.5 & 62.7 & 1311.8 & 226.8 & 549.2 & 12.4 & 985.0 & 6.8 & 1780.1 \\
\hline Teff & 16.7 & 151.7 & 13.9 & - & 134.3 & 316.5 & 38.9 & 46.9 & 1.0 & - & 6.2 & 93.0 \\
\hline Barley & 66.7 & 291.3 & 57.8 & - & 0.0 & 415.8 & & & & & & \\
\hline Wheat cv. Chikugoizumi & & & & & & & 19.6 & 505.5 & 189.1 & - & 62.4 & 776.5 \\
\hline Wheat cv. Minaminokaori & & & & & & & 26.7 & 391.3 & 275.6 & - & 57.2 & 750.8 \\
\hline
\end{tabular}

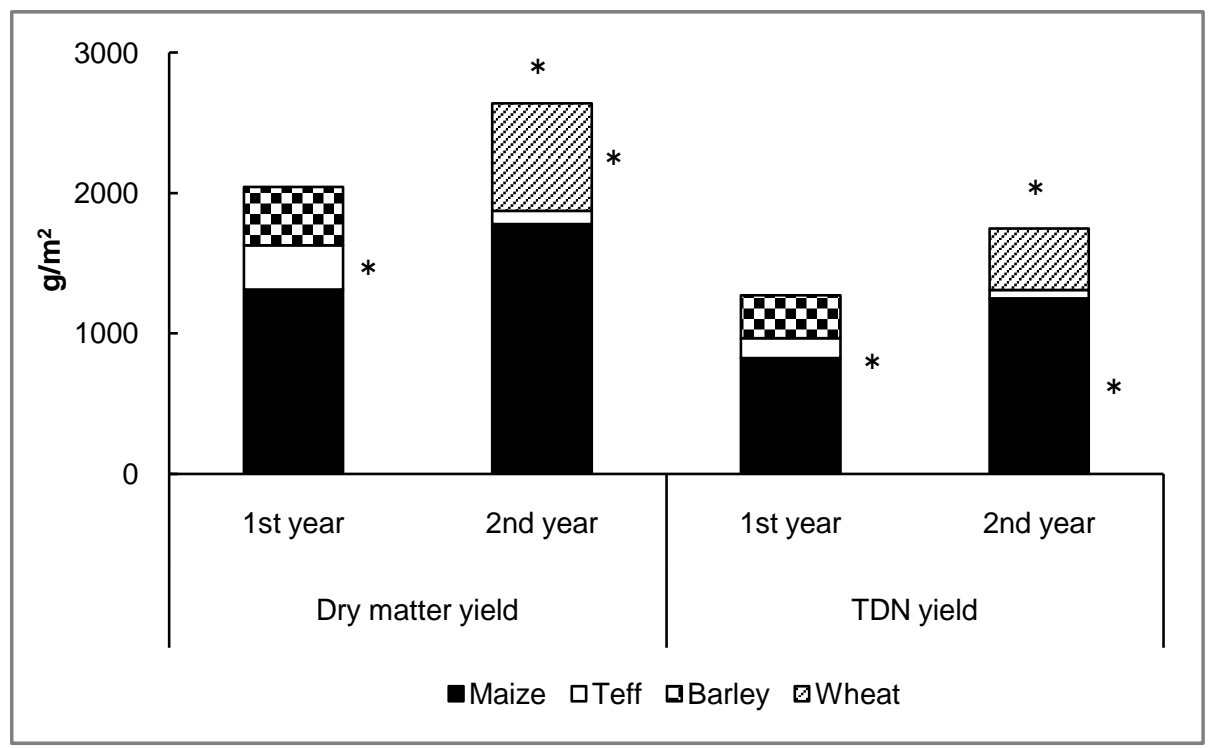

Figure 5. Dry matter yield and TDN yield of triple-cropping system in the first and second seasons $(2013-2015) .{ }^{*}: \mathrm{P}<0.05$. 
yields in the double cropping of maize with Italian ryegrass were reported at 2,189 and $1,885 \mathrm{~g} \cdot \mathrm{m}^{-2}$, respectively, showing that the total DM and TDN yields in the second season of the current study achieved at about $20 \%$ and $11 \%$ higher than those in the statistical data.

\section{Discussion}

DM yield was higher in wheat than in barley, while forage quality attributes in CP, IVDMD and TDN content were superior in barley to those in wheat. In the current triple cropping system, wheat was harvested in May when the maize cropping season is started. Therefore, combining of high quality and short growth potential was suggested for barley as the suitable winter forage crop. In the current study, we tried to cultivate newly introduced tropical grass species of teff, combined to the summer and winter crops. However, DM yield of teff was quite low in both seasons, due to competition against weedy species. In a teff variety trial in South Charleston, Ohio, "Moxie" yielded higher by $8 \%$ than "Tiffany" [15], which was a reversed ranking in the current study, although the current research was conducted in the different year. In the United States [16], competition between teff and weeds is also a serious matter for establishment and the first-cut harvest. The only chemical option available (herbicide) for weed management in teff is to apply glyphosate. The glyphosate apply to weeds prior to planting teff. Some researcher showed that competition between teff and weeds after herbicide application was minimal due to the vigorous teff stand [17]. In the previous pot cultivation, growth in teff was not significantly affected by high moisture stress nor chemical fertilizer application rate [18]. Therefore, it remains to be solved for the optimum management system for weed management, selection of cultivar and sowing rate of teff cultivation. In the spring-maize, sowing date was earlier at late March by 52 days in the second season (2014) than at mid-May in the first season (2013), obtaining the favorable DM yield and TDN content in the second season. It is suggested that early-spring sowing of maize should be recommended to have less opportunity in the growing season to face to the climatic disasters, such as low precipitation in the summer season in the current research in 2013 and typhoon damage.

\section{Conclusion}

In the current study, we tried a triple cropping system incorporating newly introduced tropical grass of teff into maize and winter cereal crops. Forage yield and quality of the triple cropping system was determined for two growing seasons. Triple cropping was the combination of spring-maize, tropical grass of teff and winter barley in the first season and the same maize and teff combined of winter wheat in the second season. In the first growing season, summer period had higher mean air temperature and lower precipitation than in the normal year, leading to lower DM and TDN yields compared with the conventional ma- 
ize-Italian ryegrass (IR) cropping system. However, annual total DM and TDN yields in the second season were higher than those in the conventional maize-IR system. In both growing seasons, teff yielded quite low due to poor establishment by weed competition, suggesting for the further research needed against weed damage. In the spring-maize, early-sowing in late March tended to have favorable DM and TDN yields compared with ordinary May-sowing of maize.

\section{References}

[1] Ministry of Agriculture, Forestry and Fisheries (MAFF) (2016) Shirowomegurujyousei.

http://www.maff.go.jp/j/chikusan/sinko/lin/1_siryo/pdf/meguji_data_1607.pdf

[2] Kodama, Y. (2009) Ethiopian Staple Food: Injura. Feature Series, What Is Staple Food in the Third World? Ajiken World Trend, 161, 18-19. http://d-arch.ide.go.jp/idedp/ZWT/ZWT200902_012.pdf

[3] Hager, A.S., Lauck, F., Zannini, E. and Arendt, E.K. (2012) Development of Gluten-Free Fresh Egg Pasta Based on Oat and Teff Flour. European Food Research and Technology, 235, 861-871. https://doi.org/10.1007/s00217-012-1813-9

[4] Gebremarian, M.M., Zarnkow, M. and Becker, T. (2014) Teff (Eragrostis tef) as a Raw Material for Malting, Brewing and Manufacturing of Gluten-Free Foods and Beverages: A Review. Journal of Food Science and Technology, 51, 2881-2895. https://doi.org/10.1007/s13197-012-0745-5

[5] Balcha, A., Gretzmacher, R. and Vollmann, J. (2006) Genetic Variation in Nitrogen-Use Efficiency of Teff. Journal of Plant Nutrition and Soil Science, 169, 704-710. https://doi.org/10.1002/jpln.200625102

[6] Miller, D. (2009) Teff Grass: A New Alternative. University of California Cooperative Extension.

http://alfalfa.ucdavis.edu/+symposium/2009/files/talks/09WAS19_Miller_Tef.pdf\#s earch='Teff+grass\%EF\%BC\%9AA+new+alternative

[7] Davison, J., Laca, M. and Creech, E. (2012) The Potential for Teff as an Alternative Forage Crop for Irrigated Regions. University of Nevada Cooperative Extension, USA. http://alfalfa.ucdavis.edu/+symposium/proceedings/2011/11-86.pdf

[8] Norberg, S., Roseberg, R., Charlton, B. and Shock, C. (2009) Teff: A New Warm Season Annual Grass for Oregon. Oregon State University Extension Service, Oregon.

http://ir.library.oregonstate.edu/xmlui/bitstream/handle/1957/20545/em8970-e.pdf

[9] Goto, I. and Minson, D.J. (1977) Prediction of the Dry Matter Digestibility of Tropical Grasses Using Pepsin-Cellulase Assay. Animal Feed Science and Technology, 2, 247-253. https://doi.org/10.1016/0377-8401(77)90028-1

[10] Kyushu Okinawa Agricultural Research Center (NARO) (1994) Estimation of Nutritive Value of Corn in Warm Region. Result Information 1994.

http://www.naro.affrc.go.jp/project/results/laboratory/karc/1994/konarc94-15.html

[11] Institute of Agricultural Production (1994) Suitable Cultivation Condition of High Quality Wheat "Chikugoizumi”. Fukuoka Agriculture and Forestry Research Center. http://www.farc.pref.fukuoka.jp/farc/seika/seikah2-6/6-11.pdf

[12] Institute of Crop Science (2001) Wheat Cultivation Manual. MAFF, Tokyo. http://www.naro.affrc.go.jp/patent/breed/0100/0108/001410.html 
[13] Japan Livestock Industry Association (JLIA) (2009) Standard Tables of Feed Composition in Japan, 1-245.

[14] Ministry of Agriculture, Forestry and Fisheries (MAFF) (2015) Harvest Survey. http://www.maff.go.jp/j/tokei/kouhyou/sakumotu/sakkyou_kome/

[15] Best Forage (2017) Moxie Teff Grass, Best Forage, LCC, USA. https://www.bestforage.com/product/moxie-teff-grass/

[16] Lindaquist, J. (2014) Teff Grass Is Gaining in Popularity as an Alternative Forage Crop in Michigan. Michigan State University.

http://msue.anr.msu.edu/news/teff_grass_is_working_in_hay_crop_rotations

[17] Roseberg, R.J., Norberg, S., Smith, J., Charlton, B., Rykbost, K. and Shock, C. (2006) Yield and Quality of Teff Forage as a Function of Varying Rates of Applied Irrigation and Nitrogen: Research in the Klamath Basin 2005. Annual Report. OSU-AES Special Report, 1069, 119-136.

[18] Idota, S., Ishii, Y. and Fukuyama, K. (2015) Effects of Soil Moisture and Fertilization Treatments on the Agronomic Traits of Teff (Eragrostis tef) in Southern Kyushu, Japan. Agricultural Sciences, 6, 1003-1013. https://doi.org/10.4236/as.2015.69095 